\title{
Surgery Patient
}

National Cancer Institute

\section{Source}

National Cancer Institute. Surgery Patient. NCI Thesaurus. Code C158375.

A patient who is undergoing a surgical procedure. 